\section{MANANEEMEN SUPERVISI KILNIS \\ (Meningkatkan Profesionalisme Guru dan Mutu Pembelajaran)}

Banyak guru yang menilai supervisi sebagai bentuk penilaian tentang baik-buruk performance guru saat berdiri di depan kelas. Konsep tersebut salah karena memahami konsep supervisi klinis secara kerdil. Supervisi klinis dimaksudkan sebagai upaya pemberian bantuan, dorongan dan meningkatkan performansi guru agar lebih baik dalam mengelola proses pembelajaran. Dalam konteks sekolah sebagai organisasi pendidikan, supervisi merupakan bagian proses administrasi dan manajemen. Di satu sisi supervisi berperan untuk melengkapi fungsi-fungsi administrasi yang ada di sekolah sebagai fungsi terakhir yaitu penilaian terhadap semua kegiatan demi mencapai tujuan. Di sisi lain, supervisi berperan dalam mengoptimalkan tanggung jawab dari semua program. Supervisi berkaitan dengan semua upaya penelitian yang tertuju pada semua aspek proses akademik dan non akademik yang merupakan faktor penentu keberhasilan pengelolaan pembelajaran. Apabila semua kondisi aspek-aspek tersebut diketahui secara rinci dan akurat maka dapat dengan mudah dan tepat pula mengambil langkah demi peningkatan kualitas organisasi secara khusus proses pembelajaran di sekolah.

Ada dua asumsi yang mendasari praktik supervisi klinis: Pertama, pembelajaran merupakan aktivitas yang sangat kompleks yang memerlukan pengamatan dan analisis secara berhati-hati melalui pengamatan dan analisis. Supervisor pembelajaran dengan mudah akan membantu dan mengembangkan kemampuan guru dalam mengelola proses pembelajaran. Kedua, guru-guru yang profesionalnya ingin dikembangkan dengan pendekatan kolegial daripada dengan cara yang outoritarian. Supervisi klinis adalah pembinaan kinerja guru dalam mengelola proses pembelajaran (Sullivan \& Glanz, 2005).

Buku Manajemen Supervisi Klinis sangat membantu setiap pembaca terutama pengelola lembaga pendidikan dan para guru untuk pengembangan profesional dan memotivasi kerja guru serta memperperbaiki proses pembelajaran yang kurang efektif. Dalam pengelolaan pembelajaran di kelas agar dapt berjalan dengan baik dan bermutu, maka perlu dilakukan pembinaan performasi guru. Selain pembinaan performansi, pengetahuan lain tentang supervisi dan aspek-aspek penting dan mendasar (konsep, tahapan, teknik dan perangkat-perangkat penting) dalam pelaksanaan supervisi klinis di sekolah perlu diketahui oleh para tim supervisor dan terutama guru. Pelaksaan supervisi klinis yang baik dan benar serta dilakukan secara disiplin dan berkala, dapat membantu meningkatkan mutu pembelajaran dan meningkatkan profesionalisme guru.

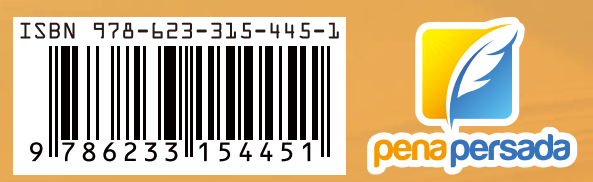

Yohanes Umbu Lede, M. Pd

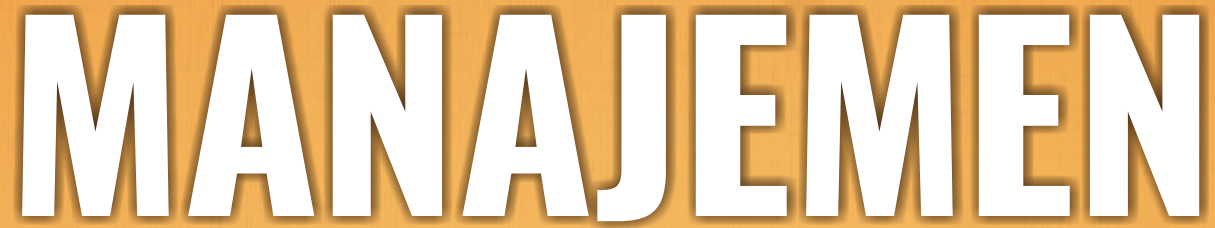

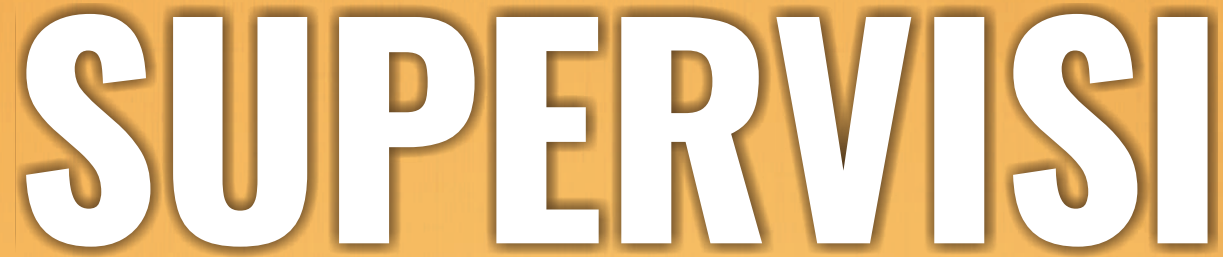

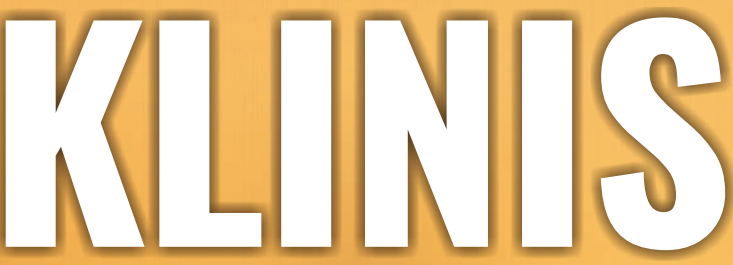

\section{(Meningkatkan Profesionalisme Guru dan Mutu Pembelajaran)}




\section{MANAJEMEN SUPERVISI KLINIS (MENINGKATKAN PROFESIONALISME GURU \\ DAN MUTU PEMBELAJARAN)}

Yohanes Umbu Lede, M. Pd

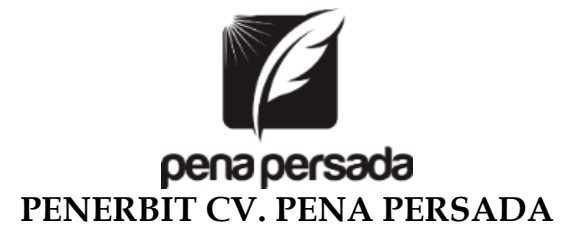




\title{
MANAJEMEN SUPERVISI KLINIS \\ (MENINGKATKAN PROFESIONALISME GURU \\ DAN MUTU PEMBELAJARAN)
}

\author{
Penulis: \\ Yohanes Umbu Lede, M. Pd
}

ISBN: 978-623-315-445-1

Editor:

Rusfik Yulli Anur wati

Design Cover:

Retnani Nur Briliant

Layout:

Hasnah Aulia

Penerbit CV. Pena Persada

Redaksi:

Jl. Gerilya No. 292 Purwokerto Selatan, Kab. Banyumas

Jawa Tengah

Email: penerbit.penapersada@gmail.com

Website: penapersada.com Phone: (0281) 7771388

Anggota IKAPI

All right reserved

Cetakan pertama: 2021

Hak Cipta dilindungi oleh undang-undang. Dilarang memperbanyak karya tulis ini dalam bentuk apapun tanpa izin penerbit 


\section{KATA PENGANTAR}

Segala puji senantiasa kita panjatkan Kehadirat Tuhan Yang Maha Esa, atas segala Rahmat dan Karunia-Nya, akhirnya penulis dapat menyelesaikan penyusunan buku yang berjudul "Manajemen Supervisi Klinis (Meningkatkan Profesionalisme Guru dan Mutu Pembelajaran)“. Saya menyadari bahwa tanpa bantuan dan bimbingan dari berbagai pihak sangatlah sulit bagi saya untuk menyelesaikan karya ini. Oleh karena itu, saya mengucapkan banyak terima kasih pada semua pihak yang telah membantu penyusunan buku ini. Sehingga buku ini bisa hadir di hadapan pembaca.

Buku ini membahas tentang manajemen supervisi klinis dalam meningkatkan profesionalisme guru dan mutu pembelajaran. Pendidikan merupakan komponen terpenting dalam merespon pembangunan. Tanpa pendidikan, setiap individu tidak dapat menyumbangkan hal berarti bagi kemajuan dan kesejahteraan bersama. Keberhasilan pendidikan dipengaruhi oleh berbagai unsur seperti: guru, siswa, pengelolaan dan pembiayaan. Unsur-unsur tersebut sangat berperan penting dalam menentukan keberhasilan pendidikan (mutu yang dihasilkan). Guru sebagai pelaku utama dalam proses pendidikan merupakan ujung tombak karena langsung berhadapan dengan siswa sebagai subyek dan obyek pendidikan. Di beberapa daerah di Indonesia sistem pendidikannya sudah sangat maju dengan pengelolaan yang sangat baik dan tentunya menghasilkan output yang handal dan langsung digunakan oleh masyarakat dan terjun dalam dunia kerja. Namun, tidak dapat dipungkiri bahwa terkadang dalam proses pendidikan di sekolah ini mengalami penurunan dari sisi kualitas. Menyikapi situasi sekaligus mengantisipasi situasi demikian, maka sekolah-sekolah perlu menerapkan sebuah model supervisi yakni supervisi klinis yang sangat diyakini membawa dampak perubahan yang sangat bagus di dalam keseluruhan proses pendidikan yang berlangsung di sekolah ini. 
Penulis menyadari bahwa buku ini masih jauh dari kesempurnaan. Oleh karena itu kritik dan saran yang membangun sangat dibutuhkan guna penyempurnaan buku ini. Akhir kata saya berharap Tuhan Yang Maha Esa berkenan membalas segala kebaikan semua pihak yang telah membantu.

Penulis 


\section{DAFTAR ISI}

KATA PENGANTAR iii

DAFTAR ISI $\mathrm{V}$

\section{BAB I PENDAHULUAN}

A. Peran Pendidikan Dalam Pembangunan Nasional .............. 1

B. Guru Sebagai Ujung Tombak Pendidikan............................. 3

C. Penerapan Supervisi Klinis di Sekolah ................................... 6

\section{BAB II SUPERVISI KLINIS}

A. Konsep Dasar Supervisi Klinis............................................ 9

B. Ciri Supervisi Klinis............................................................ 13

C. Tujuan Supervisi Klinis .......................................................... 17

\section{BAB IIITEKNIK DAN TAHAPAN SUPERVISI KLINIS}

A. Model Supervisi ............................................................... 19

1. Model Supervisi Klinis .................................................... 19

2. Model Supervisi Konvensional ......................................... 20

3. Model Supervisi Ilmiah .................................................... 20

4. Model Supervisi Artistik ................................................... 20

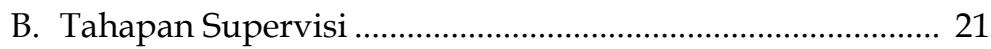

C. Teknik Umum Supervisi Klinis............................................ 32

D. Bidang Garapan Supervisi ................................................... 37

BAB IVSUPERVISI KLINIS DAN PROFESIONALISME GUR

A. Definisi Profesionalisme Guru ............................................ 40

B. Aspek-Aspek Profesionalisme Guru ..................................... 43

C. Faktor-Faktor Dalam Meningkatkan Profesionalisme Guru

D. Peranan Supervisi Klinis Terhadap Profesionalisme Guru 46

BAB V SUPERVISI KLINIS DALAM PENINGKATAN MUTU PEMBELAJARAN

A. Definisi Mutu Pembelajaran .................................................. 52

B. Faktor-Faktor Dalam Mutu Pembelajaran............................. 55

C. Peranan Supervisi Klinis Dalam Peningkatan Mutu Pembelajaran

DAFTAR PUSTAKA 64 


\section{MANAJEMEN SUPERVISI KLINIS \\ (MENINGKATKAN PROFESIONALISME GURU \\ DAN MUTU PEMBELAJARAN)}




\section{BAB I \\ PENDAHULUAN}

\section{A. Peran Pendidikan Dalam Pembangunan Nasional}

Kemajuan di berbagai bidang kehidupan mengharuskan setiap individu manusia memiliki kompetensi, keterampilan dan kreatifitas serta berkarakter. Upaya melahirkan manusia yang berkompeten, terampil, kreatif dan berkarakter tentu bukan sebuah langkah yang mudah. Dibutuhkan kerjasama yang baik dan menyeluruh dari semua elemen yang berperan agar dapat mencapai tujuan tersebut. Terlebih khusus dalam menghadapi tantangan global yakni kemajuan iptek yang setiap saat berkembang. Dengan demikian, perlu dipersiapkan generasi-generasi terdidik melalui pendidikan formal yang mampu bersaing secara global sehingga manusia Indonesia tidak menjadi penonton.

Pendidikan adalah proses pelatihan dan pengembangan pengetahuan, keterampilan, pikiran, dan karakter khususnya melalui pendidikan formal (Sagala, 2007: 1). Pendidikan bukanlah semata-semata menyiapkan individu untuk dapat menyesuaikan diri dengan lingkungannya melainkan lebih diarahkan pada upaya pembentukan pribadi dan kesediaan setiap individu melestarikan lingkungan dalam jalinan yang harmonis. Pendidikan merupakan komponen terpenting dalam merespon pembangunan. Tanpa pendidikan, setiap individu tidak dapat menyumbangkan hal berarti bagi kemajuan dan kesejahteraan bersama. Kaum intelektual selain mempunyai pengetahuan yang baik mereka juga mampu memiliki keterampilan dan karakter yang baik yang dapat disumbangkan dalam hidup bersama. Harapan dan cita-cita luhur ini mesti menjadi perhatian bersama setiap elemen, baik pemerintah, sekolah dan masyarakat. Setiap elemen tersebut hendaknya menyadari bahwa lingkungan sekitar dapat berubah jika terjadi kemungkinan lebih banyak orang 
mengenyam pendidikan. Kerja sama setiap elemen dalam mendorong generasi baru yang terdidik untuk mengenyam pendidikan perlu dilakukan secara sungguh-sungguh dan serius. Tentu upaya ini harus didukung melalui sebuah kebijakan sehingga dapat menjadi acuan bagi siapapun dalam melaksanakan sebuah program. Dan kebijakan yang dihasilkan mestinya memberikan perhatian yang lebih besar dan peluang yang lebih banyak terutama bagi dunia pendidikan.

Pendidikan hendaknya disadari menjadi salah satu bangunan dasar bagi setiap individu yang mengenyam pendidikan demi menyongsong masa depan yang lebih cerah, cerdas dan berkarakter. Hal ini merupakan sebuah tanggung jawab pembangunan dari pemerintah yang dapat ditindaklanjuti oleh pihak sekolah yang menjadi pelaku utama dalam proses pendidikan. Guru dalam hal ini mempunyai peran yang sangat penting dalam menentukan masa depan anak-anak didik. Peran guru diharapkan dapat melahirkan individu yang berkualitas dan berkompeten. Guru diharapkan pula dapat menjalankan proses pendidikan sesuai dengan aturan dan mekanisme yang ada dan yang sudah ditetapkan. Dengan demikian, langkah mereka dapat dipastikan mendukung apa yang menjadi cita-cita pembangunan nasional yakni mencerdaskan kehidupan bangsa. Pola, aturan dan mekanisme yang dipakai baik oleh pihak sekolah secara institusi maupun oleh guru secara individu mesti mencerminkan dan sesuai dengan standar pendidikan nasional. Tujuan pendidikan menghasilkan generasi yang cerdas (terampil, berpengetahuan dan berkarakter) hendaknya menjadi acuan bagi setiap guru dalam melaksanakan tugasnya. Tujuan ini hendaknya menjadi dasar pijakan mereka di antara sekian banyak harapan lain dalam mengimplementasikan setiap kebijakan dalam dunia pendidikan. Guru hendaknya mempunyai kemampuan dan kreatifitas untuk mengimplementasikan secara sederhana bagi anak didik. 


\section{B. Guru Sebagai Ujung Tombak Pendidikan}

Keberhasilan pendidikan dipengaruhi oleh berbagai unsur seperti: guru, siswa, pengelolaan dan pembiayaan. Unsur-unsur tersebut sangat berperan penting dalam menentukan keberhasilan pendidikan (mutu yang dihasilkan). Diharapkan unsur-unsur tersebut saling menopang satu sama lain. Maju mundurnya pendidikan sangat ditentukan oleh keterkaitan dari semua unsur tersebut. Dalam konteks pendidikan terutama untuk meningkatkan kualitas pendidikan, unsur yang sangat berperan adalah guru. Guru merupakan unsur yang mempunyai peran utama dalam kemajuan dan keberhasilan proses pendidikan. Guru adalah subyek atau pelaku utama dan terpenting dalam pendidikan. Guru merupakan ujung tombak karena langsung berhadapan dengan siswa sebagai subyek dan obyek pendidikan. Sekolah yang hadir dengan sebuah kurikulum yang bagus, memiliki sarana prasarana yang memadai dan partisipasi anak didik dalam proses belajar mengajar sangat bagus tetap saja tidak akan berhasil apabila peran gurunya sangat lemah. Peran guru sebagai ujung tombak pendidikan mesti disadari sebagai yang paling mendasar. Guru sebagai ujung tombak dalam pendidikan hendaknya memiliki kompetensi-kompetensi yaitu: kompetensi pedagogik, kompetensi kepribadian, kompetensi profesional, dan kompetensi sosial. Apabila semua kompetensi di atas dimiliki oleh guru, maka tingkat keberhasilan pendidikan pun akan semakin bagus dan menunjukkan kualitas yang dapat diandalkan dan terkredibel. Guru hendaknya menyadari akan setiap kompetensi yang dimiliki sehingga dapat ditingkatkan terus-menerus. Hilangnya salah satu atau bahkan beberapa kompetensi dari dalam diri seorang guru akan berdampak pula pada sebuah kegagalan dalam proses pendidikan. Artinya proses pendidikan yang mempunyai perencanaan yang sangat bagus dengan segala macam persiapan yang bagus pula terkadang tidak didukung oleh sumber daya manusia yang baik pula (SDM guru). Berhasil tidaknya sebuah pendidikan sangat tergantung pada 
guru yang berkompeten sehingga kinerjanyapun akan semakin lebih baik. Karena kompetensi guru menjadi hal terpenting dalam proses pendidikan, penting menjadi prioritas utama dalam upaya meningkatkan mutu pendidikan.

Guru sebagai pelaku utama dalam proses pendidikan hendaknya diberi bantuan, dinilai, dievaluasi (disupervisi) dalam konteks bukan untuk mencari-cari kesalahan atau kekurangan. Guru hendaknya mendapat perhatian dari pengawas sekolah, kepala sekolah atau pihak lain yang berwenang dalam mengevaluasi guru (supervisor). Kepala sekolah atau pihak yang berwenang hendaknya melakukan supervisi demi mendukung kinerja guru untuk meningkatkan kualitas pendidikan. Guru perlu disupervisi sehingga melalui kegiatan ini mereka menyadari bahwa kinerja mereka hendaknya diperbaiki dan akhirnya berjalan sesuai dengan apa yang menjadi harapan pemerintah yaitu melahirkan generasi baru yang unggul dalam segi pengetahuan, kreativitas dan karakter.

Realitas yang terjadi selama ini bahwa supervisi dipandang kurang penting dalam proses pendidikan. Supervisi dilakukan oleh pihak sekolah hanya semata-mata formalitas dan bukannya lahir dari sebuah kesadaran individual akan pentingnya supervisi demi meningkatkan mutu pendidikan (pembelajaran) dalam konteks pembangunan manusia secara utuh dan menyeluruh. Tak jarang kita menemukan ada kegiatan supervisi hanya dipandang perlu untuk dilakukan jika dalam konteks mendesak atau karena tuntutan dari pihak atasan (pemerintah). Dengan kata lain, kegiatan supervisi dilakukan hanya karena tuntutan aturan dan dorongan dari pihak atasan semata. Substansi dan tujuan utama dari supervisi akhirnya hilang dan tidak dimaknai secara baik dan mendalam oleh hampir sebagian besar pihak yang berkecimpung dalam dunia pendidikan (Barinto dalam Jurnal Tabularasa PPS UNIMED Vol.9 No.2, Desember 2012). 
Proses supervisi yang dilakukan oleh supervisor atau kepala sekolah selain untuk menilai kompetensi guru, supervisi hendaknya dilakukan demi menilai keseluruhan proses yang dilakukan oleh guru. Apakah guru telah bekerja dan menjalankan tugasnya dengan benar. Arikunto (2004; 41) menyatakan bahwa pendidikan bertujuan:

1. Meningkatkan kinerja siswa sekolah dalam perannya sebagai peserta didik yang belajar dengan semangat tinggi agar dapat mencapai prestasi belajar yang optimal.

2. Meningkatkan kinerja guru sehingga mampu membimbing guru dan siswa.

3. Meningkatkan keefektifan dan keefisienan penggunaan sarana prasarana.

4. Meningkatkan kualitas pengelolaan sekolah.

5. Meningkatkan kualitas situasi umum sekolah.

Dalam proses pendidikan, guru tidak hanya menjalankan fungsi sebagai pemindah ilmu pengetahuan (Transfer of Knowledge) dari guru ke murid, tetapi juga berfungsi sebagai orang yang menanamkan nilai (values), membangun karakter (character building) serta mengembangkan potensi besar yang dimiliki siswa secara berkelanjutan. Guru merupakan faktor sangat penting dalam mewujudkan sistem pendidikan yang bermutu dan efisien. Karena guru menjadi figur utama dalam proses belajar mengajar, maka setiap guru diharapkan memiliki karakteristik (ciri khas) kepribadian yang ideal sesuai dengan persyaratan yang bersifat psikologispedagogis. Pembentukan kepribadian guru menuju guru profesional adalah salah satu cara yang tepat untuk bangkit dalam keterbatasan yang dimiliki. Guru sangat berperan dalam membantu perkembangan peserta didik untuk mewujudkan tujuan hidupnya secara optimal (Mulyasa, 2005:10). Satu hal yang akan menjadi titik perhatian kita adalah "bagaimana merancang guru masa depan yang menjadi teladan". Guru masa depan adalah guru yang memiliki kemampuan, dan keterampilan bagaimana dapat menciptakan hasil 
pembelajaran secara optimal, selanjutnya memiliki kepekaan di dalam membaca tanda-tanda zaman, serta memiliki wawasan intelektual dan berpikiran maju, tidak pernah merasa puas dengan ilmu pengetahuan yang sudah ada. Sesuai dengan perkembangan masyarakat dan perkembangan pendidikan di negara kita, maka paradigma tenaga pendidikan pun sudah seharusnya mengalami perubahan, khususnya yang berkaitan dengan supervisi atau kepengawasan pendidikan ini. Dengan paradigma lama tergambar bahwa kegiatan tidak dapat diharapkan berjalan lancar dengan sendirinya sesuai dengan rencana dan tujuan yang telah ditetapkan, jika tidak diawasi.

\section{Penerapan Supervisi Klinis di Sekolah}

Pengaruh dari banyaknya lulusan perguruan tinggi dan belum dimanfaatkannya lulusan tersebut, berdampak pula dalam dunia pendidikan. Banyak tenaga pengajar atau guru yang mengajar tidak sesuai dengan faknya selama menempuh studi di perguruan tinggi. Hal ini sangat terasa jika kita melihat kondisi pendidikan di daerah-daerah pedalaman. Selain karena minimnya lapangan pekerjaan, tenaga pendidik yang dipakai di instansi pendidikan didasarkan karena hubungan kedekatan dengan kepala sekolah atau instansi terkait yang ada di daerah. Hal ini berdampak pada terhambatnya proses belajar mengajar di sekolah. Proses pendidikan yang terjadi tidak sesuai dengan mekanisme, aturan dan tuntutan yang ada. Oleh karena itu, peran kepala sekolah atau supervisor di sini sangat dibutuhkan untuk mendampingi atau bahkan mengambil sikap tegas demi menjaga kualitas lulusan atau kompetensi output. Dengan demikian, output tadi dapat membawa perubahan bermakna dan berarti dalam kehidupan bermasyarakat.

Pengawasan oleh supervisor perlu dilakukan secara berkala dan teratur serta up to date mengingat perkembangan zaman dengan berbagai hal baru yang mau tak mau harus dialami oleh setiap individu manusia terutama pelaku di dunia pendidikan. Ada berbagai kemajuan zaman yg selalu up to date sehingga penting pula mengaktualkan kemampuan guru lewat 
pendampingan dari supervisor. Di sisi lain, aturan, kebijakan, metode yang diterapkan pemerintah untuk meningkatkan kualitas mutu pendidikan hendaknya direspon secara baik oleh setiap elemen. Kebijakan ini memang dinilai sulit tetapi tujuannya menjadi sangat jelas terutama dalam menangani proses perkembangan pendidikan anak didik. Pengawas atau supervisor hendaknya bekerja keras dan mempunyai pemahaman yang lebih baik tentang pola pendekatan supervisi sehingga efektifitas proses supervisi dapat berjalan dengan baik. Diharapkan supervisor memahami secara baik kendala dan hambatan yang dialami oleh guru sehingga dapat mengambil langkah konkret dan tepat untuk membantu mereka dalam mengatasi persoalan demi peningkatan mutu anak didik dan demi pencapaian tujuan pendidikan. Supervisor sudah memahami secara baik dan mendalam tentang faktorfaktor baik internal maupun eksternal yang mempengaruhi peningkatan mutu pendidikan.

Di beberapa daerah di Indonesia sistem pendidikannya sudah sangat maju dengan pengelolaan yang sangat baik dan tentunya menghasilkan output yang handal dan langsung digunakan oleh masyarakat dan terjun dalam dunia kerja. Namun, tidak dapat dipungkiri bahwa terkadang dalam proses pendidikan di sekolah ini mengalami penurunan dari sisi kualitas. Hal ini dipengaruhi oleh berbagai faktor yang ada yang dapat ditemukan dalam lembaga pendidikan ini. Situasi ini pula membawa dampak pada kualitas pelayanan yang bisa dikatakan kadang-kadang menurun dari waktu ke waktu. Menyikapi situasi sekaligus mengantisipasi situasi demikian, maka sekolah-sekolah perlu menerapkan sebuah model supervisi yakni supervisi klinis yang sangat diyakini membawa dampak perubahan yang sangat bagus di dalam keseluruhan proses pendidikan yang berlangsung di sekolah ini.

Proses pelaksanaan supervisi klinis di sekolah bisa berjalan dan diyakini dalam implementasinya membawa dampak yang sangat bagus apabila direncanakan dan dilaksanakan dengan baik berdasarkan regulasi dan tuntutan 
yang ada. Dengan implementasi supervisi klinis sangat membantu para guru dalam meningkatkan profesionalisme guru dan mutu pembelajaran yang berlangsung di sekolah ini. Dalam upaya untuk tetap terus meningkatkan mutu pendidikan di sekolah ini, kepala sekolah dan juga bersama tim dengan sangat baik memberi perhatian besar terhadap proses pelaksanaan supervisi klinis di sekolah. Fokus utama yakni memberi perhatian pada keberadaan sumber daya manusia yakni kompetensi (pengetahuan dan keterampilan) yang dimiliki oleh guru dalam memahami secara lebih baik tentang penanganan proses pendidikan yang bermutu dan kontekstual. Guru secara khusus dan institusi secara keseluruhan menghendaki adanya sebuah pembaharuan dalam artian melakukan pola-pola pendekatan baru demi menghidupkan kembali proses pendidikan yang sewaktu dianggap sudah mulai menurun mutunya. Guru secara pribadi dan sekolah sebagai institusi menyadari benar-benar apa yang menjadi kelemahan sehingga terbuka untuk melakukan evaluasi dalam bentuk supervisi klinis. Langkah penting ini diharapkan mampu meningkatkan terus-menerus mutu pendidikan secara berjenjang dan kontekstual seiring dengan perkembangan yang dialami oleh institusi sekolah secara menyeluruh. Proses pelaksanaan manajemen supervisi klinis di sekolah dapat mendorong perubahan khususnya dalam peningkatan pendidikan di sekolah ini. Dengan adanya metode pendekatan yang bagus, tingkat kesadaran yang tinggi, inisiatif yang lahir dari dalam diri setiap elemen di sekolah tersebut, dan kerja sama yang saling mendukung dapat meningkatkan kualitas pendidikan yang lebih baik. 


\section{BAB II SUPERVISI KLINIS}

\section{A. Konsep Dasar Supervisi Klinis}

Istilah supervisi baru muncul pada tiga dasawarsa terakhir. Pada awalnya istilah yg sering digunakan adalah inspeksi, pemeriksaan, pengawasan atau penilikan. Dalam konteks sekolah sebagai organisasi pendidikan, supervisi merupakan bagian proses administrasi dan manajemen. Di satu sisi supervisi berperan untuk melengkapi fungsi-fungsi administrasi yang ada di sekolah sebagai fungsi terakhir yaitu penilaian terhadap semua kegiatan demi mencapai tujuan. Di sisi lain, supervisi berperan dalam mengoptimalkan tanggung jawab dari semua program. Supervisi berkaitan dengan semua upaya penelitian yang tertuju pada semua aspek yang merupakan faktor penentu keberhasilan. Apabila semua kondisi aspek-aspek tersebut diketahui secara rinci dan akurat maka dapat dengan mudah dan tepat pula mengambil langkah demi peningkatan kualitas organisasi.

Supervisi berasal dari dua kata bahasa Inggris, yaitu super dan vision. Super berarti di atas dan vision yang berarti melihat. Makna ini masih serumpun dengan inspeksi, pemeriksaan, dan pengawasan, dan penilikan, dalam arti kegiatan yang dilakukan oleh atasan terhadap bawahannya. Supervisi merupakan salah satu istilah yang berada dalam rumpun pengawasan tetapi sifatnya lebih humanity. Dalam pelaksanaannya pun tidak dimaksudkan untuk mencari-cari kesalahan melainkan lebih pada memberikan pembinaan agar kondisi kualitas pekerjaan yang sedang disupervisi dapat diketahui kekurangannya dan kemudian mengambil langkah konkret untuk memperbaikinya (Suharsimi Arikunto, 2004: 13). 
Konsep supervisi klinis, mula-mula diperkenalkan dan dikembangkan oleh Morris L. Cogan, Robert Goldhammer, dan Richarct Weller di Universitas Harvard pada akhir dasawarsa lima puluhan dan awal dasawarsa enam puluhan. Ada dua asumsi yang mendasari praktik supervisi klinis: Pertama, pembelajaran merupakan aktivitas yang sangat kompleks yang memerlukan pengamatan dan analisis secara berhati-hati melalui pengamatan dan analisis. Supervisor pembelajaran dengan mudah akan membantu dan mengembangkan kemampuan guru dalam mengelola proses pembelajaran. Kedua, guru-guru yang profesionalnya ingin dikembangkan dengan pendekatan kolegial daripada dengan cara yang otoritarian. Supervisi klinis adalah pembinaan kinerja guru dalam mengelola proses pembelajaran (Sullivan \& Glanz, 2005). Sedangkan menurut Cogan (1973), supervisi klinis merupakan kegiatan pembinaan performansi guru dalam mengelola proses belajar mengajar. Jadi supervisi klinis adalah kegiatan pembinaan guru dalam meningkatkan kinerja atau unjuk kerja dalam proses pembelajaran. Menurut Sergiovanni (1987) ada dua tujuan supervisi klinis: 1) pengembangan profesional dan 2) memotivasi kerja guru dan memperperbaiki proses pembelajaran yang kurang efektif.

Walaupun ada banyak cara untuk melakukan pengamatan, model untuk melakukan pengamatan atas kerja guru relatif standar, diterima dan memiliki basis penelitian yang dihargai (Sullivan,1980; Adam dan Glickman, 1984; Pavan, 1985; Nolan, Hawkes, dan Francis, 1993; Glickman, 2002). Faktanya, lebih dari 90 persen administrator sekolah di bagian selatan dan tengah AS telah mengutip pengetahuan mereka tentang penggunaan struktur ini dengan guru (Bruce dan Hoehn, 1980). Secara umum, model ini disebut supervisi klinis yang berasal dari karya awal dari Morris Cogan dengan para pengawas guru-guru intern di Universitas Harvard. Supervisi klinis milik Cogan (1973) dan buku dari Robert Goldhammer yang juga berjudul Supervisi Klinis (1969) adalah publikasi awal dari karya ini. Sejak itu, banyak perbaikan dan 
perubahan terhadap supervisi klinis yang telah dilakukan (Costa dan Garmston, 1985; Acheson dan Gall, 1992; Anderson dan Snyder, 1993; Goldhammer, Anderson, Krajewski, 1993; Pajak, 1993, 2002).

Supervisi klinis adalah sebuah konsep dan sebuah struktur. Goldhammer, Anderson, dan Krajewski (1993) mengulas sembilan karakteristik supervisi klinis sebagai sebuah konsep:

1. Teknologi untuk memperbaiki pola pengajaran.

2. Intervensi yang disengaja dalam proses pembelajaran.

3. Berorientasi tujuan, menggabungkan kebutuhan sekolah dengan semakin bertambahnya kebutuhan personal orangorang yang bekerja di dalam sekolah.

4. Hubungan kerja profesional antara guru dan pengawas.

5. Membangun saling kepercayaan pada derajat yang tinggi, yang dicerminkan dalam pemahaman, dukungan, dan komitmen pada pertumbuhan.

6. Dilakukan dengan sistematis, walaupun mengharuskan sebuah perubahan metodologi yang fleksibel dan terus menerus.

7. Menciptakan ketegangan yang produktif (sehat) untuk menjembatani celah antara yang nyata dan yang ideal.

8. Berasumsi bahwa pengawas sangat mengetahui hal-hal terbaik mengenai analisis pembelajaran dan pengajaran, namun juga tahu interaksi antara manusia yang produktif.

9. Mengharuskan adanya pelatihan pradinas (untuk pengawas), khususnya dalam teknik pengamatan, dilanjutkan dengan evaluasi hasil kerja tentang pendekatan yang efektif (Carl D. Glickman, 2010).

Supervisi klinis adalah pembinaan performansi guru dalam mengelola proses pembelajaran (Sullivan dan Glanz, 2005) dalam Lantip dan Sudiyono (2011: 112). Supervisi klinis merupakan supervisi yang dilakukan berdasarkan adanya keluhan atau masalah dari guru yang disampaikan kepada supervisor. Supervisi klinis dapat disebut juga sebagai bentuk 
supervisi yang difokuskan pada peningkatan mengajar dengan melalui siklus yang sistematik, dalam perencanaan, pengamatan serta analisis yang intensif dan cermat tentang penampilan mengajar yang nyata, serta bertujuan mengadakan perubahan dengan cara yang rasional. Ide untuk memberlakukan supervisi klinis bagi guru muncul ketika guru tidak harus disupervisi atas keinginan kepala sekolah sebagai supervisor tetapi atas kesadaran guru datang ke supervisor minta bantuan mengatasi masalah yang dihadapi ketika berproses di dalam kelas. Kepala sekolah sebagai supervisor akademik seyogyanya memiliki pengetahuan dan menguasai penerapan supervisi klinis (Pusat Pengembangan Tenaga Kependidikan Badan Pengembangan Sumber Daya Manusia Pendidikan dan Kebudayaan dan Penjaminan Mutu Pendidikan Kementerian Pendidikan dan Kebudayaan 2014: Bahan Ajar Kepala Sekolah Supervisi Akademik Implementasi Kurikulum 2013: https://www.google.co.id/ files.wordpress. com-supervisi-akademik-2.pdf).

Pemerintah telah mengambil kebijakan dengan membuat peraturan dalam bentuk perundang-undangan. Landasan yuridis ini akan menjadi sebuah rujukan bagi siapapun atau pihak yang terkait dalam dunia pendidikan berkenaan dengan pelaksanaan supervisi pendidikan. Supervisi pendidikan secara umum, mempunyai landasan yuridis sebagai berikut:

1. Pada bagian umum penjelasan atas Undang-Undang Republik Indonesia tahun 1945 menyatakan bahwa tujuan nasional adalah untuk melindungi segenap bangsa dan seluruh tumpah darah Indonesia dan untuk memajukan kesejahteraan umum, mencerdaskan kehidupan bangsa, dan ikut melaksanakan ketertiban dunia berdasarkan kemerdekaan, perdamaian abadi, dan keadilan sosial. Dalam mewujudkan pencapaian tujuan nasional tersebut, peran pendidikan menjadi salah satu faktor penting dan sangat menentukan. Dalam pasal 31 Undang-Undang Dasar Negara Republik Indonesia Tahun 1945 mengamanatkan bahwa (1) setiap warga Negara berhak mendapat 
pendidikan; (2) setiap warga Negara wajib mengikuti pendidikan dasar dan pemerintah wajib membiayainya; (3) pemerintah mengusahakan dan menyelenggarakan satu sistem pendidikan nasional, yang meningkatkan keimanan dan ketakwaan serta akhlak mulia dalam rangka mencerdaskan kehidupan bangsa yang diatur dengan undang-undang; (4) Negara memprioritaskan anggaran pendidikan sekurang-kurangnya $20 \%$ dari anggaran pendapatan dan belanja Negara serta dari anggaran pendapatan dan belanja daerah untuk memenuhi kebutuhan penyelenggaraan pendidikan nasional; dan (5) pemerintah memajukan ilmu pengetahuan dan teknologi dengan menjunjung tinggi nilai-nilai agama dan persatuan bangsa untuk kemajuan peradaban serta kesejahteraan umat manusia (Jasmani, 2013: 18-19).

2. Undang-Undang Nomor 2 Tahun 1989 Tentang Sistem Pendidikan Nasional dan Peraturan Pemerintah Nomor 29 Tahun 1990 Tentang Pendidikan Menengah ditegaskan bahwa pada jenjang pendidikan menengah, selain pengawasan, kepala sekolah juga mendapat tugas sebagai supervisor yang diharapkan dapat setiap kali berkunjung ke kelas dan mengamati kegiatan guru yang sedang mengajar.

3. Undang-Undang No. 20 Tahun 2003 Sistem Pendidikan Nasional bab XI tentang Pendidik dan Tenaga Kependidikan pasal 39-44.

\section{B. Ciri Supervisi Klinis}

Dalam pelaksanaan supervisi klinis di institusi sekolah, supervisor dan pengawas memahami secara baik ciri-ciri supervisi. Ciri-ciri supervisi klinis yakni:

1. Bantuan yang diberikan bukan bersifat instruksi atau memerintah. Ciri ini diharapkan dapat tercipta hubungan manusiawi antara supervisor dan yang disupervisi, yang pada akhirnya guru-guru memiliki rasa aman. Guru tidak merasa disudutkan sehingga dapat menimbulkan rasa takut yang berlebihan. 